\title{
"Pleistocene Modernity" and its Emergence in the Korean Peninsula: A critical review of its issues and evidence
}

Yongwook Yoo*

\section{Introduction}

The emergence of anatomically modern humans (H. sapiens, AMH hereafter) and its cultural output are mind-boggling issues on a global scale but quite intriguing in diverse ways; ${ }^{1}$ discussing the topic of AMH in Korea seems neither scientifically plausible nor archaeologically fathomable. Putting the AMH and its heritage on the Korean archaeological agenda, we need to clearly understand that the geographical domain must be extended beyond the national boundaries of modern Korea. Besides, taken into consideration is that Korea is a politically unusual domain influenced with a tattered modern history of colonization and separation resulting from the cold-war. ${ }^{2}$ The historical and archaeological research

* Professor, Department of Archaeology, Chungnam National University, Daejeon, S. Korea.

1 Charles L. Brace, "Modern Human Origins: Narrow Focus or Broad Spectrum," in Conceptual Issues in Modern Human Origins Research, ed. Geoffrey A. Clark and Catherine M. Willermet (New York: Aldine de Gruyter,1997), 11-27; Catherine M. Willermet and Brett Hill, "Fuzzy Set Theory and Its Implications for Speciation Models," in Conceptual Issues in Modern Human Origins Research, ed. Geoffrey A. Clark and Catherine M. Willermet (New York: Aldine de Gruyter,1997), 77-88.

2 Yoo Yongwook, "A Story of Their Own: what happened and what is going on with 
of Korea has been conducted totally differently in the North and the South respectively. For the North, one of its archaeological goals is to find propaganda to hail its nationalistic spirits and to secure its autonomous land tenure by taking a reclusive, clandestine but dogmatic pace in obtaining and interpreting relevant evidence. ${ }^{3}$ It is, therefore, of a premature notion that Korean archaeological data can academically contribute to the understanding of modern human emergence and dispersals in a global scale.

In spite of this handicapped circumstance, I would like to briefly demonstrate the status quo of relevant Korean research with a more aloof but critical manner. The reason for this is two-fold. First, although the nature of archaeological data is to be further examined, its existence and context of discovery need to be introduced, summarized, and exposed to the wider audience. In other words, apart from biased interpretations and their impact, the factual data needs to be systematically displayed for future research since most researchers, especially westerners, are not aware of the true characteristics of the Korean data.

The second reason is to remove the emotional tone and hyperbole from the Korean palaeolithic narratives. Unbounded storytelling with a handful of materialistic evidence in Korean palaeolithic is highly concerned with its research attitudes, and I do not think this tendency is solely unique to the Korean case. Because of the endemic perspective on the peopling of their country, Koreans highly value the antiquity and perenniality of their folk lineage; this "nostalgic rendering" and/or habitus operativus has continuously influenced the research attitude of Korean palaeolithic studies. The immediate result is that the dating of Korean palaeolithic data tends to far-antedate their real dates. In addition, the quality of data is often

North Korean Archaeology?," in Archaeology of the Communist Era: A Political History of the 20th Century, ed. Ludomir R. Lozny (New York: Springer 2017), 275-294.

3 Yoo, "A Story of Their Own: what happened and what is going on with North Korean Archaeology?" 
exaggerated and utilized as a medium to convey the idea that Korean ancestors commanded (or "flourished with") magnificent and remarkable prehistoric "culture" or "civilization."

In order to overcome this sentimental research bias, I would like to be more attentive than ever to the realistic interpretation of available data. A critical review of Korean palaeolithic research will be the starting point of such an endeavor and this article will be mainly focused on the current understanding of the emergence of so-called "Pleistocene Modernity" ${ }^{4}$ in Korea. Briefly summarizing the nature of available data, it can be argued that most Korean palaeolithic remains are the behavioral imprint of AMH who have resided in the Korean Peninsula since ca 40 kya. Except for some arguable and controversial older data, Korean fossil remains and lithic assemblages as well as a handful of faunal data belong to Upper Pleistocene (125- 10 kya); more reliable archaeological data with higher resolution of scientific measurements are definitely from the full-fledged Upper Palaeolithic temporal range (ca 40- 10 kya).

Taking this large temporal range as a chronological boundary, I would like to examine the cultural/technological accomplishments attained and developed by $\mathrm{AMH}$, as well as to outline the paleoanthropological /archaeological evidence of the Korean peninsula. The main tasks are to 1) introduce the material data, 2) associate them with the environmental background, and 3) discuss their cultural/technological meanings on the local (Korean), regional (East Asian), and global scales respectively.

\section{East Asian paleoenvironment in general during the Upper Pleistocene}

In order to examine the issue of Pleistocene modernity, the environ-

4 Milford H. Wolpoff and Rachel Caspari, "What Does It Mean to be Modern," in Conceptual Issues in Modern Human Origins Research, ed. Geoffrey A. Clark and Catherine M. Willermet (New York: Aldine de Gruyter,1997), 28-44. 
mental and archaeological background of the Upper Pleistocene Korea need to be considered first. The global environment has drastically changed since the final Tertiary (ca 2.5mya) and the ice age has come and gone every hundreds of thousand years during the Pleistocene era. Each glacial/interglacial period has been marked with stadial and interstadial subdivisions and palaeolithic people have consequently undergone numerous environmental changes and adjusted their lifestyles accordingly. These lifestyles yielded current available archaeological records under totally different environmental conditions from now.

An analysis of deep-sea marine isotope oxygen furnished a detailed panorama of Pleistocene environmental change. More information has become available through the study of polar icecaps from Greenland and the Antarctic since the 1970s. As indicated by this long-term climatic evidence, the Korean Peninsula has been isolated from the full coverage of the Asiatic continental ice sheet in the north. ${ }^{5}$ The monsoon was one of the major factors responsible for climatic change, and rugged terrain and diverse river channels turned different microenvironments into niches for local fauna/flora and the hominid population.

It can be generally summarized that a relatively mild environment reduced survival stress during the latter part of Middle Pleistocene in the Korean Peninsula and adjacent parts of East Asia. With the onset of the MIS 6, however, serious climatic deterioration occurred in the northeastern part of the continent. Possibly because of more severe climatic condition, the archaeological record during this period is scarce and hominid's cultural marking, archaeological evidence of human occupation, is not well established in the Korean palaeolithic chronostratigraphy.

On a more macro-geographical scale, numerous sub-stages of warm/cold cycles as of MIS5e are observed from the continental data. Summarizing the cyclic climate data, a sort of consensus can be made that a general temperature reduction occurred across the entire Asian continent

5 Yi Seonbok, Dongbuk Asia Guseokgi Yeongu (A Study of Northeast Asian Palaeolithic) (Seoul: Seoul National University Press 1989). 
and ecologically favorable areas for hominid survival were centripetally constricted around the middle-eastern part of Asia until the Last Glacial Maximum (LGM of ca $20 \mathrm{kya}$ ). ${ }^{6}$ Ironically, as a reactionary process, more vigorous migration and propagation of survival technology were triggered and instigated by the gradual ecological crisis on the continent. It is also suggested that a continuous environmental deterioration could not entirely hinder the gradual expansion of the hominid habitat during the Upper Pleistocene. The area below $40^{\circ} \mathrm{N}$ did not constitute extremely harsh conditions for the positive adaptation of the Asian hominids. ${ }^{7}$ Except for northern Manchuria, the Tibetan Plateau, and some local spots of tremendously low productivity, almost every part of eastern China and Korea was occupied by hominids modifying their survival strategy such as using unique localized lithic technology.

\section{Topography and fluvial system of the Korean Peninsula}

In order to elucidate the population history of the Korean Pleistocene, some physical factors should be taken into closer consideration. The northern part of Korea is connected to continental Asia and currently occupied by North Korea. The whole peninsula ranges between $33^{\circ} 06^{\prime}$ and $43^{\circ} 01^{\prime}$ latitude and between $124^{\circ} 11^{\prime}$ and $131^{\circ} 53^{\prime}$ longitude. The total area of the peninsula is about $221,000 \mathrm{~km}^{2}$ including all adjacent islands. Geologically, Korea is a part of a stable continental land mass but located at the margin of the Circum-Pacific Orogen where vigorous orogenic movement still occurs.

$6 \mathrm{Pu}$ Qingyu, "Quaternary glaciers in China," in The Quaternary of China, ed. Zhang Zonghu (Beijing: China Ocean Press 1991), 240-274; Shi Yafeng, "Glaciers and Glacial Geomorphology in China," in Quaternary Geology and Environment in China, ed. Liu Tungsheng (Beijing: Science Press 1991), 16-27.

7 Yi, Dongbuk Asia Guseokgi Yeongu, 112. 


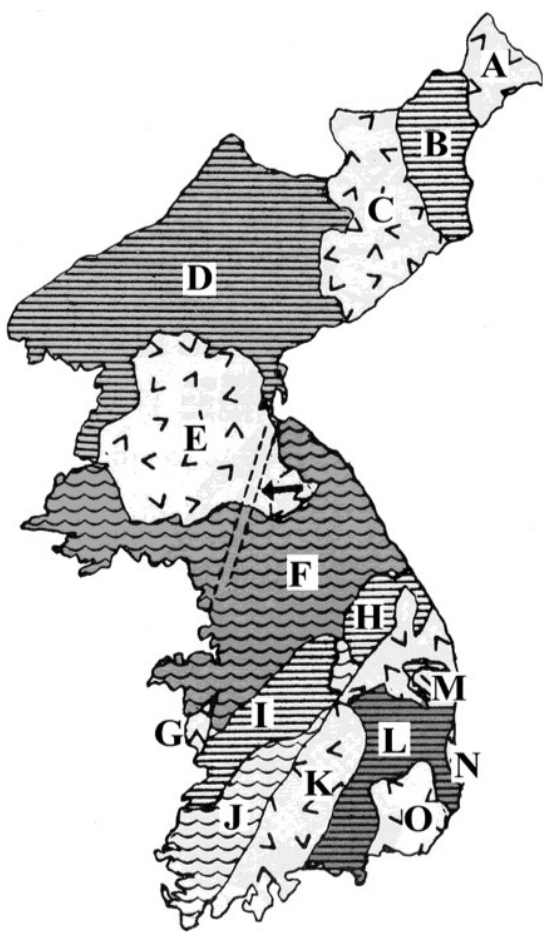
A) Tuman Trough
B) Hambuk Craton
C) Mach'ǒnryŏng Geosyncline
D) P'yŏngbuk Craton
E) P'yŏngan Basin
F) Kyŏnggi Craton
G) Okmasan Trough
H) Non-metamorphic Crest
I) Okch'ǒn Geosybcline
J) Yŏngsan River Trough
K) Sobaek Mt. Craton
L) Kyŏngsang Basin
M) Yŏnyang Trough
N) P'ohang Basin
O) Miryang Trough

Fig. 1. Geological zones of the Korean Peninsula ${ }^{8}$

The general topography of Korean Peninsula was formed by the "Taebo Orogeny" from the early Jurassic to the Cretaceous Period (ca 180$120 \mathrm{Mya}$ ). Violent thrusting and innumerable folds accompanied by large scale faulting produced a series of high mountains. This movement occurred mainly in the middle- and southern part of the peninsula and the consequences are well observed by the syntactic granites across the

8 Yi, Dongbuk Asia Guseokgi Yeongu, 36. 
"Okch’ŏn Geosyncline Belt" (I of Figure 1) which traverses from northeast to southwest.
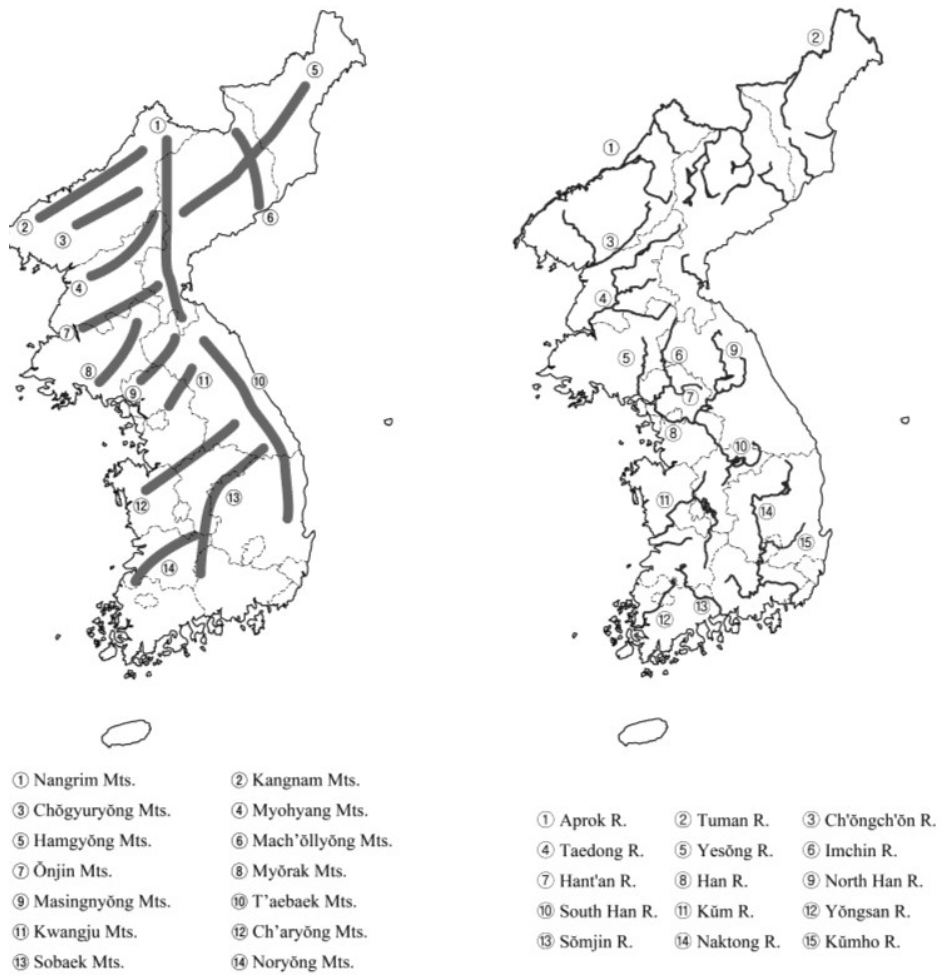

Fig. 2. Mountain ranges and major river channel systems of the Korean Peninsula

Korea is predominantly a mountainous area and most of the channel system is westward because of its west-slanting topography. The land surface consists of generally low mountain ranges with only $5 \%$ being above 1,000 meters. However, the topography is much dissected and even low mountains have steep slopes associated with a relatively early stage of the topographic developmental cycle. Two linear mountain ranges traverse the peninsula like vertebrae from North to South- the Nangrim 
and T'aebaek Mountains. Several other tributary mountain shoots emerge from these two ranges (left of Figure 2). Because of its extensive mountainous area, the peninsula is populated primarily in the midwestern and southwestern regions. Archaeological remains in Korea tend to appear sporadically but their distribution is highly clustered and unevenly dispersed among these mountain ranges.

Palaeolithic sites are located within the altitude range of $20 \mathrm{~m}$ to $70 \mathrm{~m}$ above the average sea level. This level is almost identical to that of the current residency in Korea, and generally follows along the outskirts of steep mountain slopes. In some cases, palaeolithic sites have been discovered in several regions of limestone caves which extend far above the slope range. The Okch'ŏn Belt mentioned above is a well-developed calcareous land mass with various escarpments and cavities, which is an ideal habitat both for hominids and animals. Because of the calcareous alkali environment, fossil remains are well-preserved in these cave sites, but most of the other open-air sites rarely produce animal or hominid fossils.

Other than cave and rock shelter sites, most open-air sites are distributed along the major river channels in Korea. At the northernmost border of Korea, two channels- the Amnok (Yalu in Chinese) and Tuman Riversoriginate from the Paekdu (Changbai in Chinese) Mountain and demarcate the peninsula from Manchuria. Below the Amnok and Tuman, numerous river channels run from east to west, parallel to the east-west direction of most mountain ranges ( 2 of Figure 2). In the southern part of the peninsula, three major channels-Nakdong, Sŏmchin, and Yŏngsanrun southward; these channels flow through deeply entrenched valleys and consequently develop a complex network of tributary streams along adjacent hills. The availability and accessibility of water were always a critical concern for hominids and most prehistoric sites are located adjacent to hydraulic sources such as a major river channel or a lesser tributary. Accordingly, almost all Korean palaeolithic localities are distributed near fairly large fluvial channels with a few cave sites being located in mountainous areas of higher altitude. 


\section{Evidence of hominid occupation in the Korean Peninsula: fossil records}

The population history during the Pleistocene of Korea is not welldocumented but it is quite axiomatic that the Korean Peninsula was initially populated by hominids that migrated from the continent, possibly from the northeastern part of current China. Because the eastern part of China has been connected to Korea until the LGM, ${ }^{9}$ a larger influx of a hominid population was enabled during the Upper Pleistocene time compared to the later period when the connecting land was finally submerged under the current Yellow Sea. It is, however, not plausible that the continental hominid population preferred the Korean Peninsula and voluntarily move eastward in search of more favorable habitats. The reason for this is that the Korean Peninsula is interspersed with very rugged terrains and small-scaled fluvial channels did not furnish enough productivity to host large-scale and ubiquitous hominid groups. This might be a partial reason for the fact that most Korean palaeolithic assemblages are small-scale and rarely display the evidence of long-term occupation to the extent that temporal change of lithic technological adaptation is well-documented.

Although some far earlier evidence is reported from continental China, solid palaeolithic records dated as old as Lower/Middle Pleistocene are yet to be reported in Korea; the age determination of Korean palaeolithic sediments is still controversial and reliable dating samples are hard to obtain because of extremely acidic conditions. It is, therefore, an ambiguous claim that the Korean peninsula was occupied and populated simultaneously with other parts of the Eurasian continent. According to recent data on the Pleistocene environment and relevant chronometric dates, ${ }^{10}$ a

9 Han Chang-kyun, "Hanguk guseoki Yujŏgŭi yeondae munjee taehan kochal," (On the problems of the dates of Korean Palaeolithic sites) Hanguk Guseokhi Hakbo (Journal of the Korean Palaeolithic Society) 7 (June 2003): 1-39.

10 The Korean Archaeological Society (TAKAS), Hanguk gogohak gangüi (Lectures on Korean Archaeology), (Seoul: Sahwoepyeonglon Publishing 2007). 
claim can be made that the majority of Korean palaeolithic evidence is chronologically bracketed into the Upper Pleistocene (125- 12 kya). As has been stated before, the Upper Pleistocene of Korea is characterized by a gradual deterioration of climate and biomass; this coincided with the development of local lithic technology and population migration within and outside the peninsula in response to the change of environment. A sample of hominid fossils from the Korean Peninsula and their general characteristics is presented in Table 1.

Hominid fossils are usually discovered in the same context as other faunal remains. Until now, eight cave sites, one rock shelter and one open-air site have yielded hominid fossils. Five of those eight caves (Yŏkp'ori, Sŭngnisan, Ryonggok Cave, Mandalri, and Kŭmch'ŏn) and one open-air site (Hwadaeri) are located in North Korea, while remaining cave sites (Chŏmmal Cave, Kunang Cave, and Hŭngsu Cave at Turubong) and one rock shelter (Sangsiri) are located in the limestone area in the central part of South Korea. Except for a near complete skeleton of a single juvenile individual (the "Hŭngsu Boy") from the Hŭngsu Cave at Turubong site, the remaining hominid fossils are mostly fragments of diverse body parts which cannot be attributed to a single individual. Recently there have been claims that the complete skeleton set of the Hŭngsu Boy is neither a Pleistocene nor prehistoric specimen. This claim is based on the analytical result that the extent to which his dental decay was progressed is a typical indication of post-agricultural diets and that there is no geological correlation between the original Pleistocene strata and the horizon where the skeleton was found. ${ }^{11}$

It is notable that, other than unconfirmed data from the Hwadaeri site of North Korea in Table 1, most hominid fossils are AMH. Two skulls and post-cranial bones discovered from Ryonggok Cave, originally reported to be H. erectus, have now been re-interpreted as definite AMHs based on their prominent modern-looking morphology and the dimen-

11 Lee S., Personal Communication. 
Table 1. Hominid Fossils discovered in the Korean Peninsula ${ }^{12}$

\begin{tabular}{|c|c|c|c|}
\hline Location & Age (est.) & Parts & Species \\
\hline Yǒkp'ori Cave & $\begin{array}{l}\text { M./U. Pleisto- } \\
\text { cene }\end{array}$ & Frontal, occipital, parietal & H. erectus (?) \\
\hline Sŭngnisan Cave & $\begin{array}{l}\text { M./U. Pleisto- } \\
\text { cene }\end{array}$ & Two molars, scapula, mandible & $\begin{array}{l}\text { Archaeic } H \text {. } \\
\text { sapiens }\end{array}$ \\
\hline Ryonggok Cave & $\begin{array}{l}\text { Layer } 9(46- \\
48 \text { kya } \\
\text { by U-series } \\
\text { dating) }\end{array}$ & Cranium (No.7), mandibles (No.1, 2, 6) & $\begin{array}{l}\text { Modern } H \text {. } \\
\text { sapiens (?) }\end{array}$ \\
\hline Ryonggok Cave & Layer 10 & $\begin{array}{l}\text { Cranium (No.3), mandibles (No. 4, 6) } \\
\text { femur }\end{array}$ & $\begin{array}{l}\text { Modern } H \text {. } \\
\text { sapiens }(?)\end{array}$ \\
\hline Ryonggok Cave & Layer 11 & $\begin{array}{l}\text { Temporal, frontal, mandible (fr.), } 3 \\
\text { humerus (fr.), } 8 \text { vertebrae, } 3 \text { innomi- } \\
\text { nate, } 2 \text { femur (fr.) }\end{array}$ & $\begin{array}{l}\text { Modern } H \text {. } \\
\text { sapiens }\end{array}$ \\
\hline Ryonggok Cave & Layer 12 & Maxilla (No. 8) & $\begin{array}{l}\text { Modern } H . \\
\text { sapiens }\end{array}$ \\
\hline Mandalri Cave & $\begin{array}{l}\text { Upper Pleis- } \\
\text { tocene }\end{array}$ & $\begin{array}{l}\text { Calvaria, mandible (fr.), humerus, fe- } \\
\text { mur, innominate }\end{array}$ & $\begin{array}{l}\text { Modern } H \\
\text { sapiens }\end{array}$ \\
\hline Kümch'ŏn Cave & 30 kya & Mandible, inciser, axial (fr.) & $\begin{array}{l}\text { Modern } H \text {. } \\
\text { sapiens }\end{array}$ \\
\hline Hwadaeri & 0.3 Mya (?) & Skeletal (fr.) & $\begin{array}{l}\text { Archaeic } H \text {. } \\
\text { sapiens (?) }\end{array}$ \\
\hline Chŏmmal Cave & 40- 60 kya & Phalanx, metatarsal & $\begin{array}{l}\text { Modern } H \text {. } \\
\text { sapiens }\end{array}$ \\
\hline Sangsiri & 30 kya & $\begin{array}{l}\text { Left parietal, occipital (fr.), radius, } \\
\text { right scapula, right humerus, teeth }\end{array}$ & $\begin{array}{l}\text { Modern } H . \\
\text { Sapiens }\end{array}$ \\
\hline Kunang Cave & $\begin{array}{l}\text { Upper Pleis- } \\
\text { tocene }\end{array}$ & Talus, metatarsal, phalanx & $\begin{array}{l}\text { Modern } H . \\
\text { sapiens }\end{array}$ \\
\hline $\begin{array}{l}\text { Hŭngsu Cave at } \\
\text { Turubong }\end{array}$ & 40- 50 kya (?) & $\begin{array}{l}\text { Nearly complete single juvenile indi- } \\
\text { vidual }\end{array}$ & $\begin{array}{l}\text { Modern } H \text {. } \\
\text { sapiens }\end{array}$ \\
\hline
\end{tabular}

sions of the crania. ${ }^{13}$ While three cranial fragments from the Yŏkp'ori Cave are arguably regarded as being in the category of a more archaic

12 Christopher J. Norton, "The Current State of Korean Paleoanthropology," Journal of Human Evolution 38, no.6 (June 2000): 74; Park Seon-ju and Lee Eun-Kyung, "Hanbandoeui Goinryu (Hominids of the Korean Peninsula)," Hanguk Guseokgi Hakbo (Journal of the Korean Palaeolithic Society) 7 (June 2003): 42.

13 Park and Lee, "Hanbandoeui Goinryu," 41-51. 
species (i.e. possibly H. erectus), ${ }^{14}$ it is still unclear to conclude that the Korean Peninsula was inhabited by hominids as old as the archaic form of different species from $\mathrm{H}$. sapiens. Notwithstanding opportunities that very old hominid species resided in Korea and their solid fossils are discovered in the future, we cannot go beyond the fact that discovered hominid fossils assume, whether partially or fully, anatomically modern features.

\section{Korean palaeolithic assemblages and the problem of chronology}

Archaeological assemblages are rarely associated with hominid fossils. In fact, only one hominid fossil from Mandalri ${ }^{15}$ was discovered in a primary context with portable artifacts: thirteen lithic specimens made of quartzite and obsidian, most of which are examples of microblade cores representative of terminal Upper palaeolithic technology (1 of Figure 3). In addition, a fluted antler shaft and a partly ground antler spatula were discovered with lithic assemblages. These so-called bone tools seem to have been used as a stone knapping implement ( 2 of Figure 3.). Since the provenience of these tools is not secured, however, their arguable contemporaneity with the hominid fossil is questionable.

Unlike the cases of Africa and Europe, Korean palaeolithic data as a local variation of the East Asian palaeolithic entity is not so easily divided into Lower-Middle-Upper chronological subunits. For example, 1) Korea lacks evidence of chronologically and geologically solid hominid species which can be employed to demarcate the cultural/technological evolution at the local level. 2) Technological repertoires of Korean palaeolithic assemblages are very dull and monotonous. They scarcely show temporal dynamics and any visible changes do not seem to happen for a considera-

14 Norton, "The Current State of Korean Paleoanthropology," 81.

15 Han Chang-kyun, Bukhaneui Seonsa Gogokak (Prehistoric Archaeology of North Korean) (Seoul: Baeksan Munhwasa 1990), 380-89. 


\section{Microcores}

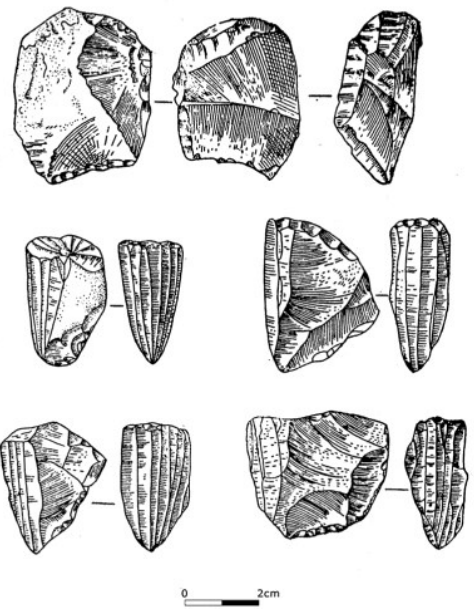

\section{Bone Tools(?)}

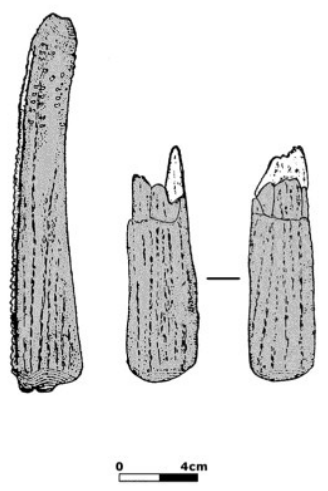

Fig. 3. Microcores and presumed bone tools discovered at the Mandalri site

bly long time before the emergence of Upper palaeolithic technology. Thus, it is hardly expected that any clear-cut chronological scheme is substantiated in the Korean and even in East Asian palaeolithic by employing such classic cultural terminologies as "Acheulian," "Mousterian," and "Aurignacian." This lack of cultural and temporal markers will be a unique characteristic of technological evolution in the palaeolithic record of Korea.

While Korean lithic assemblages display little technological development compared to the western equivalent brought about by Neanderthals, the basic mind-set and attitude toward the manufacture and use of lithic tools would not be much different from those of the Neanderthals because they are also "susceptibly produced by dint of technological provisioning strategies". ${ }^{16}$ In a sense, the difficulty in characterizing and documenting Korean palaeolithic assemblages principally lies in the less variable "displaying capacity" under relatively mild and tranquil living conditions ra-

16 Steven L. Kuhn, Mousterian Lithic Technology: An Ecological Perspective (Princeton: Princeton University Press 1995), 9. 


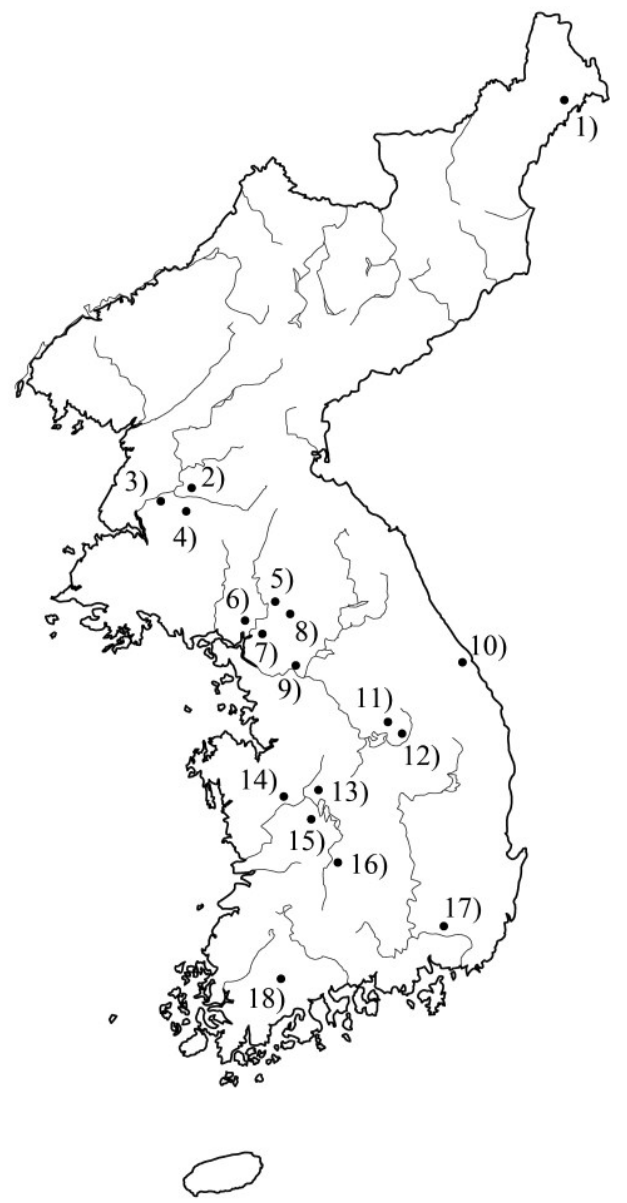
1) Kulp'ori
2) Ryonggok Cave
3) Yŏkp'ori/Sŭngnisan
4) Mandalri
5) Namgyeri
6) Kŭmp'ari
7) Chuwŏlri
8) Chŏngokni
9) Hop'yŏngdong
10) Nobong
11) Ch'angnae
12) Suyanggae
13) Mansuri
14) Sŏkchangni
15) Yongsandong
16) Chingŭnŭl
17) Koryeri
18) Taejŏn of Hwasun

Fig. 4. Major palaeolithic localities mentioned in this article 
ther than in the "monotone" of the strategies themselves. Morphological changes incurred by technological variation as a mode of adaptation to the local environment cannot be easily detected as to demonstrate the highfidelity of technical susceptibility under relatively stress-free conditions. This kind of dynamics in lithic technological evolution tends to appear simple with the usage of unsophisticated materiality within assemblages; this leads the observer to easily believe they are simply crude and underdeveloped; and some even believe that East Asian palaeolithic data are the output of culturally retarded local hominids. ${ }^{17}$

Considering the monotonous characteristics of the Korean palaeolithic in general, a substantial conclusion can be made that its periodization and/or chronology need not follow the westernized scheme. The Korean palaeolithic can be currently divided into Lower and Upper (or Early and Late) palaeolithic like other parts of East Asia. ${ }^{18}$ The Early palaeolithic incorporates whole lithic assemblages produced during the pre-modern sapiens phase. Its time span is from the Middle to earlier part of Upper Pleistocene; the earliest archaeological evidence in Korea is the Kŏmŭnmoru site of North Korea with controversial chronometric dates of 1.0- 0.5mya; the Mansuri site, possibly the oldest evidence of human occupation in South Korea, is dated around 0.5mya. Except for these several earliest dates, the majority of Korean palaeolithic dates are inclusively spread around Upper Pleistocene, quite after the MIS5e. This leads to a very provisional-but solid- speculation that the hominid occupation of the Korean Peninsula occurred significantly later than in continental mainland Asia because of its position to the far eastern corner where the presumed migratory route of the AMH could reach its last phase.

17 e.g. Hallam L. Movius Jr., Early man and Pleistocene stratigraphy in southern and eastern Asia. Papers of Peabody Museum of American Archeology and Ethnology 19, no. 5 (Cambridge: Harvard University Press 1944).

18 Gao Xing. and Christopher. J. Norton, "A critique of the Chinese 'Middle Palaeolithic," Antiquity 76 (November 2001): 397- 412; Fumiko Ikawa-Smith, "Introduction: The Early Palaeolithic Tradition of East Asia," in Early Palaeolithic in South and East Asia, ed. Fumiko Ikawa-Smith (The Hague: Mouton 1978). 


\section{Before the dawn of Pleistocene Modernity in the Korean Peninsula: archaeological evidence before AMH}

The Lower (including Middle of the western hemisphere) palaeolithic assemblages of Korea are mostly composed of crude simple tools like choppers, picks and amorphous large flakes made of quartz and quartzite. What is noteworthy is that some Acheulian-like handaxes and cleavers are recurrently discovered around the Imjin and Hantan River Area (the IHRA) $)^{19}$ of the midwestern part. Upon their first discovery in 1978, they were regarded as the ultimate counterevidence of Movius' claim that early East Asian lithic technology is devoid of Acheulian characteristics and predominantly composed of simple artifacts as chopper and choppingtools. In recent years, however, the nature of the IHRA handaxes has been re-examined with dates that are much earlier than the presumed Middle Pleistocene age and technological features that are totally different from the genuine Acheulian ones. ${ }^{20}$

Some representative earlier palaeolithic evidence and their lithic assemblages are presented here. It should be emphasized that South Korean and other international scholars have not been given access to the North Korean archaeological record; the approximate age and repertoire of lithic specimens are therefore entirely according to quite old publication materials.

\section{Kulp'ori}

This is the first Korean palaeolithic site discovered in 1962 and located at Sŏnbong County, Northern Hamgyŏng Province in North Korea. Two

19 Yoo Yongwook, Beyond the Movius Line, BAR International Series 1772 (Oxford: Hadrian Books 2008).

20 see Yoo, Beyond the Movius Line; "Jeongokri Jumeokdokieui Siganjeok Wichie Daehan Siron (A Speculation on the Temporal Horizon of Handaxes from the Chongokni Site: A Heuristic Approach)," Gogohak (Archaeology) 8, no. 1 (June 2009): 5-25. 
cultural layers are identified within the Pleistocene sediments; the lower layer (Kulpo I) yielded quartz tools and the upper layer (Kulpo II) included endscrapers and other small tools made of shale. It is believed that Kulpo I is ca 0.1mya and Kulpo II is ca 40- 30 kya. No chronometric dates are available for both layers. ${ }^{21}$

\section{Kŏmŭnmoru}

Kŏmŭnmoru was discovered and excavated in the 1960s by the Institute of Archaeology in North Korea. It is a cave site located on the escarpment of a shallow rock inselberg; some subtropical faunal remains and very crude lithic artifacts were discovered and their ESR dates are around ca 1.0mya. Considering the unstable dating and the nature of the formation process of cave deposits, its archaeological context is not believed to be intact. ${ }^{22}$

\section{Chŏngokni and other handaxe-bearing sites across the IHRA}

Chŏngokni (now Jeongok-ri) is the site of the first discovery of a handaxe in East Asia. The discovery was reported in 1978 and other handaxe localities-Kŭmp'ari, Chuwŏlri, Namgyeri, etc.-have been identified around the demilitarized zone (DMZ) between North and South Korea along the Imjin and Hantan River channels. These IHRA palaeolithic sites are commonly distributed above volcanic lava and its $\mathrm{K}-\mathrm{Ar}$ dates (ca 0.5- 0.3mya) indicate the maximum oldest date of artifact layers. It is believed that the formation of whole lithic assemblages including handaxes was initiated with a significant time-gap after a volcanic eruption; some chronometric dates, including several OSL ones, of artifactbearing sediments are predominantly younger than MIS5e. The particles of Aira Tanzawa (AT) tephra (ca 25 kya) discovered above the artifact

21 National Research Institute of Cultural Heritage Korea (NRICHK), Hanguk Gogohak Sajeon-Guseokgi Sidae (Dictionary of Korean Archaeology- The Paleolithic Age) (Daejeon: Publication Department of NRICHK 2014)

22 NRICHK, Hanguk Gogohak Sajeon-Guseokgi Sidae. 
horizon demonstrate the possible youngest date of handaxes. ${ }^{23}$ Given these dates and the geological context of artifact horizons, we can recognize that the handaxe of the IHRA is younger than the typical Acheulian one and can take an alternative position that the IHRA handaxe is not directly associated with the Acheulian acculturation from the west. More discussion on the Mode 2 technology in East Asia needs to be developed in the future. ${ }^{24}$
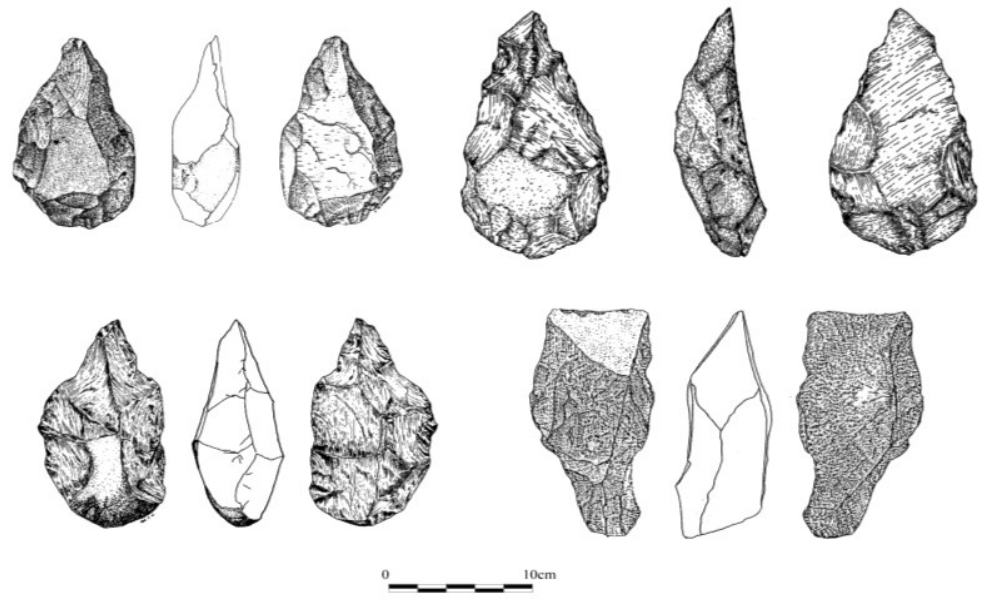

Fig. 5. Handaxes and cleavers from the Imjin-Handan River Area (IHRA), Korea

\section{Upper palaeolithic assemblages of AMH under severe environment}

The issue of the emergence of AMH in Korea is a heated debate and still needs valid archaeological data to corroborate. If blade and laminar

23 Yoo, Beyond the Movius Line; "Jeongokri Jumeokdokieui Siganjeok Wichie Daehan Siron"; Yi, Seonbok, Handaxes in the Imjin Basin (Seoul: Seoul National University Press 2011).

24 NRICHK, Hanguk Gogohak Sajeon-Guseokgi Sidae. 
lithic technology are an output of technological innovation accomplished by $\mathrm{AMH}$, the emergence of Upper palaeolithic in Korea is believed to be around 40 kya when initial blade technology was globally propagated along with the migration of AMH. As a sufficient condition for making effective blade-based toolkits, the raw material shifted from low quality (quartz and quartzite) to high quality ones (chert, rhyolite, obsidian, etc.). The Suyanggae, Sŏkjangni, Hop'yŏngdong, and Yongsandong sites are good examples of Korean local Upper palaeolithic assemblages. These assemblages share some technologically common features: 1) lithic specimens are composed of blade-dominant debitages and highly retouched tools; 2) locally available high-quality raw materials are extensively exploited; 3) some unprecedented cultural features such as house-pits, hearths, and engraved objects emerges as a result of local adaptation and human agency.

The Korean Upper palaeolithic witnessed its final phase characterized by microlithic technology during the terminal Pleistocene. Around the LGM, the environmental productivity of Korea reached its minimum and highly economizing technological solutions were sought and devised. ${ }^{25}$ Production of microblades and composite toolkits seem to be one of these solutions and successfully responded to the daily requirement in a more distressed resource management situation. This type of technology enabled the AMH groups to survive during the harsh cold periods and to welcome the beginning of the Holocene period (after 12 kya) when the temperature recovered and the sea level began to rise creating the coastline of the current Korean Peninsula.

Until now, more than two hundred palaeolithic localities have been discovered on the peninsula. Most of them are open air sites discovered near river banks and some are caves/rock shelters in the mountainous area. The important Upper palaeolithic localities and their cultural remains are briefly introduced here.

25 Han, "Hanguk Guseokgi Yujeokeui Yeondae Munjee Daehan Gochal." 


\section{Ryonggok Cave}

This locality is located at Sangwŏn County, P'yŏngyang City in North Korea. Composed of two adjacent caves, it was excavated by Kim Il-Sŏng University from 1980 to 1981 . Exact chronometric dates are not available because of the complicated formation process of cave deposits but faunal remains include some warm-climate species. Two individuals of AMH skeletons were discovered with some simple quartz tools, fragmented bones and remains of hearth. Although Ryongkok Cave is a definite prehistoric shelter inhabited by local hominids during the Upper Pleistocene, the exact date and technological /cultural characteristics of lithic specimens are not clearly understood yet. ${ }^{26}$

\section{Sŏkjangni}

Sŏkjangni is the first excavated (1964) palaeolithic site in South Korea. This site is located along the Kŭm River which flows and traverses the midwestern part of South Korea. ${ }^{27}$ Originally it was reported to have a long geological sequence from the Early to Upper palaeolithic, but the valid cultural layers of the longest sequence of Sŏkjangni are unclear. They are currently believed to have been seriously influenced by fluvial re-deposition and the original artifact horizons were partly washed out. The intact archaeological horizon in a whole sequence is the uppermost layer- Upper Palaeolithic phase- which yielded small scrapers, microliths and some supposedly engraved portable artifacts. ${ }^{28}$

26 NRICHK, Hanguk Gogohak Sajeon-Guseokgi Sidae.

27 Yoo Yongwook, "Geumgang Yuyeok Guseokgi Tujeokeui Hyeongseong Gwajeonggwa Goinryu Jeomgeo Gwajeong Siron (A Speculation on the Formation Process of Palaeolithic Sites and Hominid Occupation in the Geum River Area, Korea)," Hoseo Gogohakbo (Journal of Hoseo Archaeological Society) 33 (October 2015): 4-39.

28 Figure 6; NRICHK, Hanguk Gogohak Sajeon-Guseokgi Sidae. 

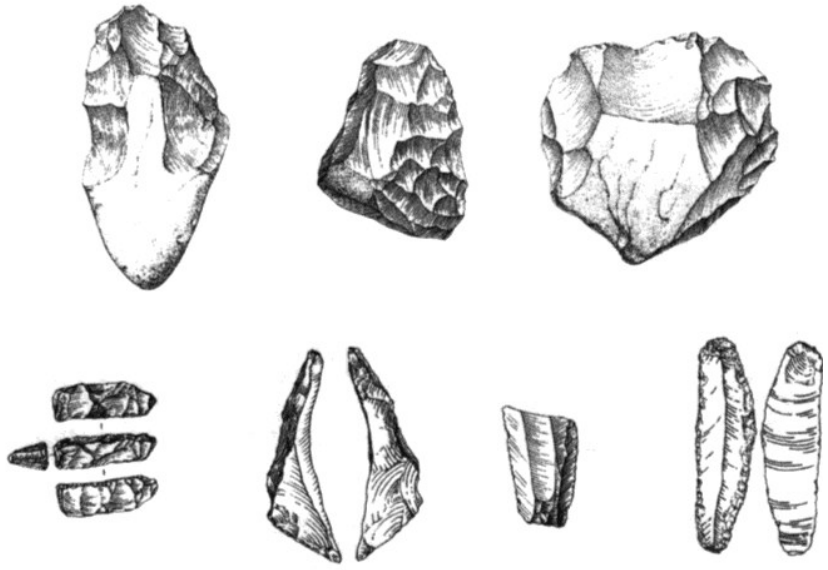

Fig. 6. Lithic specimens from the Sŏkjangni Site (No scales)

\section{Hop'yŏngdong}

Located at Namyangju City in the midwestern part of Korea, the Hop'yŏngdong site is a bowl-shaped basin surrounded by shallow hills and its primary context is largely composed of colluvial sediments. About 10,000 lithic artifacts were discovered and their raw materials are quartz, tuff, rhyolites; some obsidian of external origins was also discovered from the upper cultural layer (Figure 7.). Calculated OSL and ${ }^{14} \mathrm{C}$ ages are distributed between late MIS3 and MIS2; typical Upper/terminal palaeolithic tool types made of blades and microblades are dominant in the total assemblage. $^{29}$

\section{Suyanggae}

This locality is a vast open-air site with scattered lithic specimens on the river bank of the southern Han River. A series of excavations has been conducted from 1983 to 2014 and diverse cultural layers are distributed on the river terrace. Raw material is mostly high-quality microcrystalline shale which is easily accessible in the vicinity. Tool types include end-

29 NRICHK, Hanguk Gogohak Sajeon-Guseokgi Sidae. 

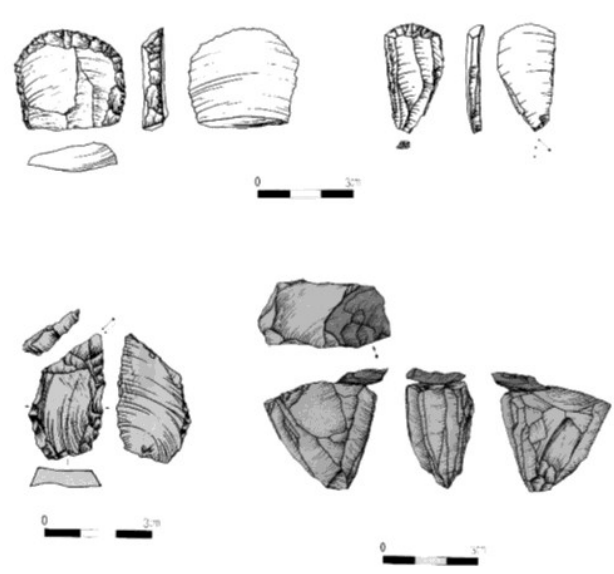
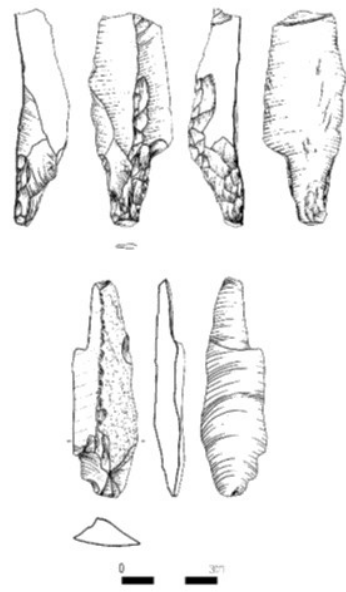

Fig. 7. Lithic tool types retrieved from the Hop'yŏngdong site.

scrapers, stemmed points, handaxes and various retouched blades. The stemmed point, a unique hunting weapon type of southern Korea, is believed to be dominant between MIS3 and 2. A ${ }^{14} \mathrm{C}$ date (18- 16 kya) of terminal Pleistocene was obtained from the upper cultural layer of the original excavation in $1983 .^{30}$

Some up-to-date results of recent excavations will be published in the near future. Unfortunately, however, its whole area is now submerged due to the later construction of large-scaled dams and the total lithic assemblage has yet to be reported to the public. In spite of its importance for Korean palaeolithic research, the quality of the relevant data published lacks valid authenticity and the reality of the whole lithic assemblage is yet to be exposed as a whole.

\section{Yongsandong}

Located inside the metropolitan area of Daejeon city near the large tributary channel of the Kŭm River, the Yongsandong site yielded well-

30 NRICHK, Hanguk Gogohak Sajeon-Guseokgi Sidae. 
preserved features of typical Upper palaeolithic assemblages in Korea.

The horizon of lithic assemblages is very limited; the sediments around the assemblage was dated by the AMS method and the ages are both around MIS2 $(19,310 \pm 790 \mathrm{BP}$ and 24,430 $\pm 870 \mathrm{BP}){ }^{31}$

It is noteworthy that the Yongsandong site has a number of flaked tools such as stemmed points, and small scrapers made of fine-grained hornfels. The majority of modified small tools were found broken and fractured without any hints of provisioning/recycling strategies such as systematically reduced cores and raw material resource procurement. It can be speculated that the stemmed points and scrapers were used for organized hunting skills including instant hiding and butchering activities around the site (Figure 8.); the lithic assemblage also indicates that this area was repetitively visited as a sort of base camp where ready-made tools were
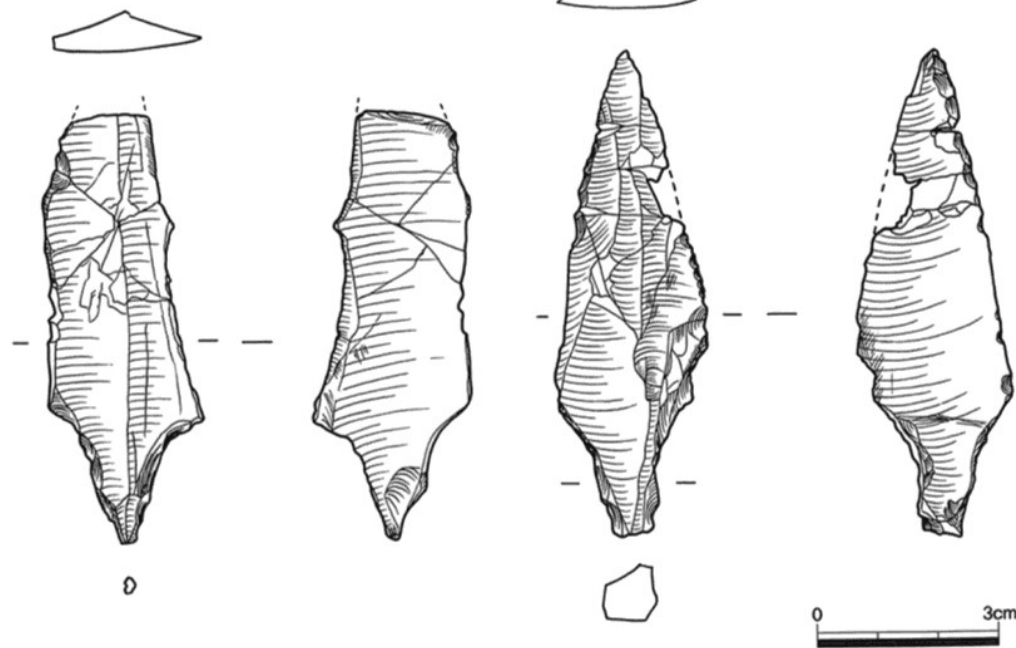

Fig. 8. Stemmed points discovered from the Yongsandong site

31 Yoo, "Geumgang Yuyeok Guseokgi Tujeokeui Hyeongseong Gwajeonggwa Goinryu chŏmgŏ Gwajeong Siron,” 33. 
imported from outside and consumed/discarded on the spot. ${ }^{32}$

\section{Chingŭnŭl}

This site is located at the far upper stream area of the Kŭm River, at the central high-altitude mountainous area of South Korea. The altitude of the Chingŭnŭl site is about $247 \mathrm{~m}$, and it is surrounded by higher slopes of steep mountain ranges. Total 12,000 lithic specimens were discovered with almost 20 lithic workplace remains and hearths. The high density of lithic distribution mainly composed of stemmed points and debitages and well-preserved in-situ manufacturing areas indicate that the Chingŭnŭl site is an example of hominid's active occupation of a high mountainous area in favor of animal resources (Figure 9.). The AMS dates $(22,850 \pm 350 \mathrm{BP})^{33}$ of a charcoal retrieved from the hearth correspond to the terminal MIS3 and MIS2 when the productivity of the Korean Peninsula was minimum and the residential movement of hominids moved up to the higher altitude so that they could obtain crucial animal resources by way of appropriate hunting strategies. ${ }^{34}$

Like the case of the Suyanggae site, the Chingŭnŭl site was excavated as a salvage program caused by a dam construction. The actual site area is now submerged and its total lithic repertoire is not well-understood among researchers because, except for several fragmentary data published

32 Yoon se-yeong, Kim Hwan-il and Yook Sim-Yeong, Daejeon Yongsandong Yujeok: Daedeok Techno-Valley Yidangye Joseongsaeop Bujinae (Excavation Report of the Yongsandong Site within the 2nd Phase Development Area of Daedeok Techno-Valley) (Daejeon: Central Institute of Cultural Heritages 2007), 115.

33 Lee Gikil. "Jinan Jingeuneul Yujeok Guseokgi Munhwacheungeui Seonggyeokgwa Euimi (The Jingeuneul Upper Palaeolithic Site in Jinan County of submerged area around the Yongdam Dam and its Significance)," Honam Gogohakbo (Journal of the Honam Archaeological Society) 19 (June 2004): 11-14.

34 e.g. Yoo Yongwook, "Seoul Mit Hangang Bonryuyeok Guseokgi Yujeokeui Ipjiwa Seongyeok (Palaeolithic settlement patterns and lithic diversities in Seoul and mainstream Han River Area)," Hyangto Seoul 88 (October 2014): 5-67. 
as peer-reviewed articles, ${ }^{35}$ there is no officially authenticated excavation report yet. It is another problem prevalent in Korea that detailed information of some renowned Palaeolithic site is not fully available to the public but only open to very limited personnel who are directly responsible for the excavation.
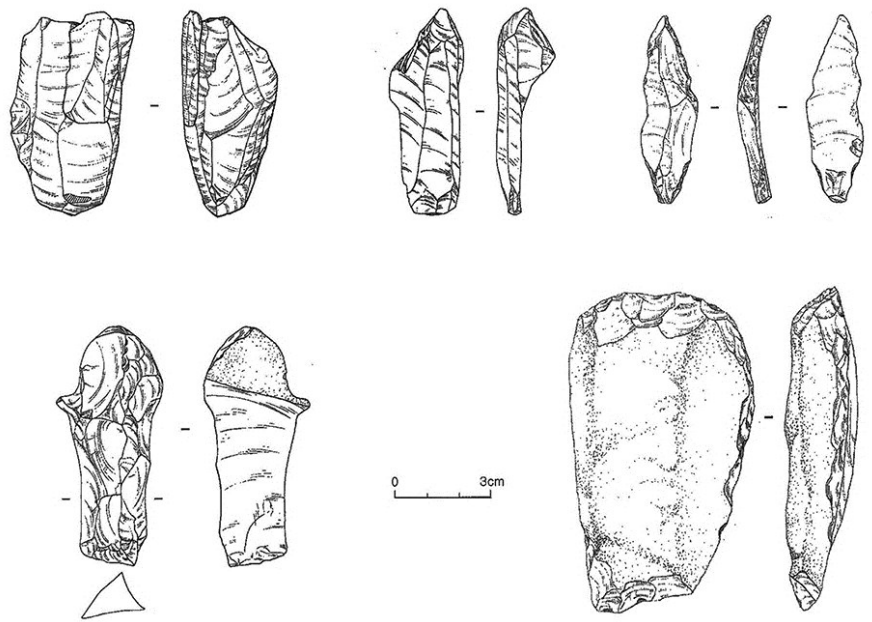

Fig. 9. Lithic types discovered from the Chingŭnŭl site

\section{Koryeri}

It is quite enigmatic that few palaeolithic sites have been reported down the Sobaek Mts. in the southeastern part of the Korean Peninsula. Some plausible reasons for this are: 1) that there was a lack of populous areas during the Pleistocene due to the natural barriers of complex mountain systems, and 2) that the evidence of palaeolithic hominid occupation was largely erased by subsequent human occupations including historical period, and was destroyed by frequent development projects and urbanization. In either case, the absence of palaeolithic records in southeastern

35 e.g. Lee, "Jinan Jingeuneul Yujeok Guseokgi Munhwacheungeui Seonggyeokgwa Euimi." 
Korea has remained an intriguing archaeological phenomenon among researchers. Up until now, there are only a handful of excavated localities in this area, and recent discoveries of palaeolithic data attract many researchers' attention in terms of cultural/technological intimacy with the Japanese palaeolithic record.

Among these recent discoveries, the Koryeri site is one of the most outstanding lithic assemblages that shed light on the hominid's local adaptation during the final phase of the Upper Pleistocene. Discovered and excavated in 1993, the Koryeri site abounds in well-made blades/bladecores and several typical Upper palaeolithic tool types. Some locally available raw materials — shales, hornfels, and andesite ${ }^{36}$-are widely exploited and the diversity of tools made of both flakes and blades is remarkable (Figure 10.). As with the cases of both Yongsandong and Chingŭnŭl, Koryeri boasts stemmed points made of numerous blade blanks as well as some mediocre scrapers and knife-shaped retouched pieces. The age of assemblage could not be measured because reliable dating source is not available; only AT volcanic ash, which has a solid age of ca $25 \mathrm{kya}$, was discovered within the stratum of assemblages.

The Koryeri assemblage indicates important archaeological facts about the hominid occupation of the Upper Pleistocene Korea; 1) by the age of MIS2, almost every part of the Korean Peninsula was occupied, possibly by the AMH groups, 2) the lithic assemblages are commonly composed of blade-based technology made of diverse local high-quality raw materials, 3) some specialized weapons like stemmed points and miscellaneous working tools such as numerous scrapers and burins became widespread reflecting a more intensive exploitation of animal resources, which was never witnessed before the MIS2

36 Chang Yong-joon, "Miryang Goryeriwa Jinju Jiphyeon Yujeokeui Guseokgi Yeongu (A Study of Miryang Gorye-ri and Jinju Jiphyeon sites in the Late Paleolithic in Korea)," Hanguk Guseokgi Hakbo (Journal of the Korean Palaeolithic Society) 34 (December 2016): 23. 

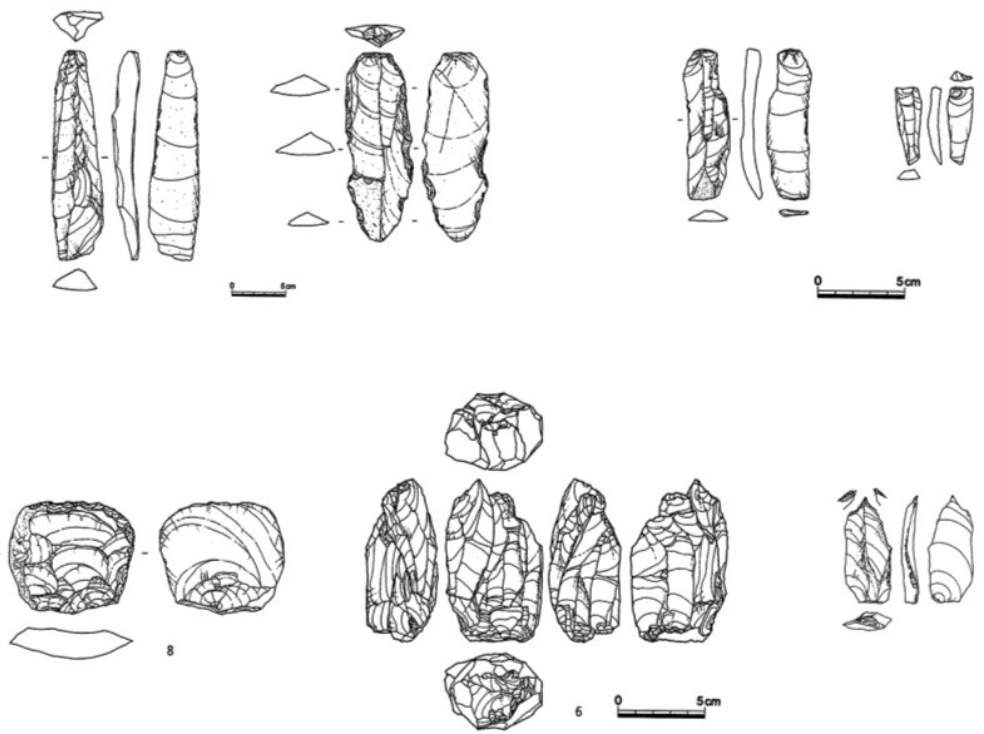

Fig. 10. Blades, microblades, refitting tools from Koryeri Site

\section{Discussion: AMH's lifestyle in the Korean Peninsula and its implication}

It is still not clear that the Upper Pleistocene hominids of Korea were exclusively an AMH population. There is no solid evidence that specific tool types such as stemmed points, elaborate blades and microliths are purely indicative of the AMH-patented technology. In spite of this, it is acceptable that the emergence of modernity in Korea is in accordance with several drastic shifts from the previous technologies. This shift was, while many other factors need to be considered, caused predominantly by the changes in the population dynamics; these population changes were also influenced by both the arrival of new species and deterioration of environment around terminal MIS3 and initial MIS2. If this shift was not solely made with the onset of population changes but was already under- 
way during the initial phase of the Upper Pleistocene, we can safely presume that there is no such an abrupt shift as to be labelled a "revolution."37

However, the tempo and velocity of this change seems to be punctuated, abrupt, and accelerated within a relatively short time span in the Korean Peninsula. For example, the very crude and monotonous mode of lithic technology based on quartz and quartzite became entirely replaced by blade-dominant, highly effective toolkits. Their raw materials are composed of unprecedentedly excellent ones and some of them ${ }^{38}$ are quite exotic and only can be obtained via cross-country transportation routes. In addition, the amount of some obviously weapon-like tools, of which origin is not well-documented, was greatly augmented. It is highly probable that these tools were immediately devised and traditionalized as a result of technological convergence in the course of repetitive animal hunting; this also signified that the implementation of violence under harsher environmental conditions was immediate. Unless otherwise narrated with the available archaeological record and its dates, we cannot but understand that the emergence of Pleistocene modernity, in other words the "Upper palaeolithic Revolution," was caused, enabled and highly inspired by the arrival of AMH and its propagation in the Korean Peninsula. In the course of this emergence, the environmental change also did play a significant role as a catalyst for this revolutionary change.

The hominids of the Korean Peninsula (including the AMH) are natural-born hunters and gatherers, but direct evidence of their active hunting and animal resource exploitation is not well-preserved in the Korean archaeological context. Some faunal remains from caves and limestone ter-

37 Sally McBrearty and Alison S. Brooks, "The Revolution that wasn't: a new interpretation of the origin of modern human behavior," Journal of Human Evolution 39 (November 2000): 453-563.

38 e.g. obsidians from Baektu Mt.; Yi Seonbok and Jwa Yong-joo, "Heukyoseok Sanji Chujeong Yeongueui Jaegeomto (On Provenance of the Prehistoric Obsidian Artifacts in Korea)," Hanguk Guseokgi Hakbo (Journal of the Korean Palaeolithic Society) 31 (June 2015): 156-180. 
rains are only available for reconstructing the paleoclimate and habitat environment; any hints on the interactions between humans and animals, especially the employment of hunting technology and butchering skills, are not well-preserved. Similar to the diet pattern of modern huntergatherers, we can surmise that palaeolithic people should have been largely dependent on plant rather than animal resources before the Upper palaeolithic; the lithic tools discovered from archaeological sites might have been used for obtaining and processing these plant resources for consumption and/or secondary uses. ${ }^{39}$

Because the AMHs were not sedentary and continuously migrated depending upon the availability of resources, the residential structure was in the form of temporary shelters like caves and simple huts made of shrubs and stones. Remains of open-air hearths from Hopyŏngdong and Chinkŭnŭl sites provide evidence demonstrating the use of temporary working places; some pit-houses discovered from the Sŏkchangri, Ch'angnae, Taechŏn of Hwasun, and Nobong sites are not suggestive of highly patterned behaviors for regularly constructing residential structures. According to the amount of undisputed archaeological data, the population level during the Korean palaeolithic period was considerably low, as low as any cultural sphere can be created and maintained from generation to generation. In addition, since the Korean Peninsula is highly mountainous and not an easy territory to navigate around, human interrelationships and any strategic migration are hardly expected.

As Clark properly stated, ${ }^{40}$ the Asian continent "experienced a complex series of dispersals, back migrations, regional diversification, isolation, reintegration, local extinctions, range extensions, displacements, replacements, radiations, continuity and discontinuity, all set against the

39 TAKAS, Hanguk gogohak gangŭi (Lectures on Korean Archaeology), (Seoul: Sahwoepyeonglon Publishing 2007).

40 Geoffrey A. Clark, "Paleolithic Archaeology and Human Paleontology in East Asia - A View from the West," Hanguk Guseokgi Hakbo (Journal of the Korean Palaeolithic Society) 30 (December 2014): 21. 
backdrop of climatic change and extending far back into the Miocene." Addressing the emergence of Pleistocene modernity in terms of the global AMH occupation is encoding this complexity rather than decoding the individual processes separately. The emergence of the AMH and its arrival in the Korean Peninsula is a very tiny piece of the puzzle that can hardly contribute to reconstructing the original picture of Pleistocene population dynamics in Asia. In particular, illustrating the emergence of Pleistocene modernity with Korean data is like trying to observe the real world "through a glass darkly" (Clark 1997). ${ }^{41}$ What is more important is to acknowledge the existence of this glass, which is also known as bias, rather than to believe that the glass is limpid enough to render a lucid image.

In sum, the palaeolithic living condition of Korea is neither poor nor abundant; it generally did not have any severe environmental conditions such as glaciers and other harsh climate; however, it did not allow physical conditions that could accommodate a large hominid population even after the arrival of the AMH groups. Because of the obscurity of Korean archaeological data, we cannot but speculate what they lived on and how they produced and utilized relevant materials. It is highly expected that the population distribution was uneven across the Korean Peninsula, and interactions among local groups were not strongly motivated because of the lack of mutual exposure. As a result, the emergence of so-called regional traditions, whether they were cultural or merely technological, can be expected in Korea no earlier than the end of the palaeolithic period. Of course, we still do not know the exact tempo and process of this "regionalization."

41 Geoffrey A. Clark, "Through a Class Darkly: Conceptual issues in Modern Human origins Research," in Conceptual Issues in Modern Human Origins Research, ed. Geoffrey A. Clark and Catherine M. Willermet (New York: Aldine de Gruyter,1997), 3-24. 


\section{Acknowledgement}

I would like to thank Prof. Song, Yang-seop and Prof. Leighanne K. Yuh for organizing and designing this special issue for Korean archaeology. I also want to appreciate two anonymous reviewers who furnished valuable comments and critiques for making a better edition of this article. All errors and mistakes are solely on me and I will be fully responsible for them

\section{References}

1. Brace, Charles. L. "Modern Human Originas: Narrow Focus or Broad Spectrum." in Conceptual Issues in Modern Human origins Research, edited by Clark, G. A and Willermet, C. M., 11- 27. New York: Aldine de Gruyter, 1997.

2. Chang, Yong-joon. 2016 "Miryang Goryeriwa Jinju Jiphyeon Yujeokeui Guseokgi Yeongu (A Study of Miryang Gorye-ri and Jinju Jiphyeon sites in the Late Paleolithic in Korea)." Hanguk Guseokgi Hakbo (Journal of the Korean Palaeolithic Society) 34 (December 2016): 20- 49.

3. Clark, Geoffrey. A. "Through a Glass Darkly: Conceptual Issues in Modern Human origins Research." in Conceptual Issues in Modern Human origins Research, edited by Clark, G. A and Willermet, C. M., 60- 76. New York: Aldine de Gruyter, 1997.

4. Clark, Geoffrey. A. "Paleolithic Archaeology and Human Paleontology in East Asia - A View from the West." Hanguk Guseokgi Hakbo (Journal of Korean Palaeolithic Society) 30 (December 2014): 3- 24.

5. Gao, X. and C. J. Norton 2001 "A critique of the Chinese 'Middle Palaeolithic."' Antiquity 76: 397- 412.

6. Han, Chang-kyun. Bukhaneui Seonsa Gogohak (Prehistoric Archaeology of North Korea). Seoul: Baeksan Munhwasa, 1990.

7. Han, Chang-kyun. "Hanguk Guseokgi Yuseokeui Yeondae Munjee 
Daehan Gochal (On the problems of the dates of Korean palaeolithic sites)." Hanguk Guseokgi Hakbo (Journal of the Korean Palaeolithic Society) 7 (June 2003): 1- 39.

8. Ikawa-Smith, Fumiko. "Introduction: The Early Palaeolithic tradition of East Asia." in Early Palaeolithic in South and East Asia. edited by F. Ikawa-Smith, 1-11. The Hague: Mouton, 1978,

9. Kim, Won-yong. Hanguk Gogohak Gaeseol (Introduction to the Korean Archaeology). Seoul: Iljisa, 1986.

10. Kuhn, Steven. L. Mousterian Lithic Technology: An Ecological Perspective. Princeton: Princeton University Press, 1995.

11. Lee, Gi-kil. “Jinan Jingeuneul Yujeok Guseokgi Munhwacheungeui Seonggyeokgwa Euimi (The Jingeuneul Upper Palaeolithic Site in Jinan County of submerged area around the Yongdam Dam and its significance)." Honam Gogohakbo (Journal of the Honam Archaeological Society) 19 (June 2004): 5- 23.

12. Lee, S. Personal Communication, 2018.

13. McBrearty, Sally. and Brooks, Alison S. "The revolution that wasn't: a new interpretation of the origin of modern human behavior." Journal of Human Evolution 39 (November 2000): 453-563.

14. Movius, Hallam. L. Jr. Early Man and Pleistocene Stratigraphy in Southern and Eastern Asia. Papers of the Peabody Museum of American Archaeology and Ethnology. 19, no.5. Cambridge: Harvard University, 1944.

15. National Research Institute of Cultural Heritage Korea (NRICHK). Hanguk Gogohak Sajeon-Guseokgi Sidae (Dictionary of Korean Archaeology- The Paleolithic Age). Daejeon: Publication Department of NRICHK, 2014.

16. Norton, Christopher. J. "The current state of Korean paleoanthropology." Journal of Human Evolution 38 (June 2000): 803-825.

17. Norton, Christopher. J. and Braun, David R. Asian Paleoanthropology - from Africa to China and Beyond. New York: Springer, 2011.

18. Park, Seon-joo and Lee, Eun-kyung. "Hanbandoeui Goinryu (Hominids of the Korean Peninsula)." Hanguk Guseokgi Hakbo (Journal of 
the Korean Palaeolithic Society) 7 (June 2003): 41 - 51.

19. Pu, Qinqyu. "Quaternary glaciers in China." in The Quaternary of China. Edited by Z. Zhang, 240-274. Beijing: China Ocean Press, 1991.

20. Shi, Yafeng. "Glaciers and glacial geomorphology in China." in Quaternary Geology and Environment in China. edited by Tungsheng Liu, 16- 27. Beijing: Science Press, 1991.

21. Willermet, Catherine. M. and Hill, Brett. "Fuzzy Set Theory and Its Implications for Speciation Models." in Conceptual Issues in Modern Human origins Research, edited by Clark, G. A and Willermet, C. M., 77- 88. New York: Aldine de Gruyter, 1997.

22. Wolpoff, Milford. H. and Caspari Rachel. "What Does It Mean to be Modern" in Conceptual Issues in Modern Human origins Research, edited by Clark, G. A and Willermet, C. M., 28-44, New York: Aldine de Gruyter, 1997.

23. The Korean Archaeological Society (TKAS), Hangukgogohak GangEui(Lectures on Korean Archaeology). Seoul: Sahwoepyeonglon Publishing, 2007.

24. Yoo, Yongwook. Beyond the Movius Line, BAR International Series 1772, Oxford: Hadrian Books, 2008.

25. Yoo, Yongwook. "Jeongokri Jumeokdokieui Siganjeok Wichie Daehan Siron (A Speculation on the Temporal Horizon of Handaxes from the Chongokni Site: a Heuristic Approach).” Gogohak (Archaeology) 8, no.1 (June 2009): 5-25.

26. Yoo, Yongwook. "Seoul Mit Hangang Bonryuyeok Guseokgi Yujeokeui Ipjiwa Seongyeok (Palaeolithic settlement patterns and lithic diversities in Seoul and mainstream Han River Area)." HyangtoSeoul 88 (October 2014): 5- 67.

27. Yoo, Yongwook. “Geumgang Yuyeok Guseokgi Yujeokeui Hyeongseong Gwajeonggwa Goinryu Jeongeo Gwajeong Siron (A Speculation on the Formation Process of Palaeolithic Sites and Hominid Occupation in the Geum River Area, Korea)." Hoseo Gogohakbo (Journal of Hoseo Archaeological Society) 33 (October 2014): 4- 39. 
28. Yoo, Yongwook. "A Story of Their Own: what happened and what is going on with North Korean archaeology?" in Archaeology of the Communist Era: a Political History of the 20th Century. edited by Ludomir R. Lonzy, 275- 94. New York: Springer, 2017.

29. Yoon, Se-yeong, Kim, Hwan-il and Yook, Sim-young. Daejeon Yongsandong Yuseok: Daedeok Techno-Valley Yidangye Joseongsaeop Bujinae (Excavation Report of the Yongsandong Site within the 2nd Phase Development Area of Daedeok Techno-Valley). Daejeon: Central Institute of Cultural Heritages, 2007.

30. Yi, Seonbok. Handaxes in the Imjin Basin. Seoul: Seoul National University Press, 2011.

31. Yi, Seonbok. Dongbuk Asia Guseokgi Yeongu (A Study of Northeast Asian Palaeolithic). Seoul: Seoul National University Press, 1989.

32. Yi, Seonbok. and Jwa Yong-joo. "Heukyoseok Sanji Chujeong Yeongueui Jaegeomto (On Provenance of the Prehistoric Obsidian Artifacts in Korea)." Hanguk Guseokgi Hakbo (Journal of the Korean Palaeolithic Society) 31 (June 2015): 156- 80. 
$\langle$ Abstract〉

\section{"Pleistocene Modernity" and its Emergence in the Korean Peninsula: A critical review of its issues and evidence}

This article critically examines the issue of the emergence of modern humans and its relevant archaeological data in Korea. Even though Korean palaeolithic archaeology is often emotionally biased in narrating the history of human occupation, the archaeological data has potential to observe how Pleistocene modernity - the occupation of anatomically modern humans (AMH) and drastic changes in material culture - was achieved and progressed on a global scale. Considering the unique geographical position and configuration of highly rough terrain on the Korean peninsula, it is hardly expected that large-scale human migration and heavy population density were possible before Upper Pleistocene. Pleistocene modernity is observed as the emergence of highly effective blade-based lithic tools and the shift of raw materials from crude to refined and exotic rocks. This technological change coincides with the arrival of anatomically modern humans inside the Korean Peninsula around 40,000 BP. It is, however, expected that the population distribution was uneven during this progress, and interactions among local hominid groups were not substantiated because mutual exposure and serious communication for target-oriented tasks were not initiated until terminal Pleistocene. As such, the regional tradition across the material culture is expected at least after the end of palaeolithic period, after Pleistocene.

Keywords: Pleistocene modernity, palaeolithic, anatomically modern humans, paleoenvironment, regional tradition 


\section{〈국문초록〉}

\section{한반도 '홍적세의 모더니티'와 그 발생에 대하여 - 주제와 자료의 비판적 검토-}

유용욱 (충남대학교 인문대학 고고학과)

본 논문은 한국에서 현생 인류의 발생 문제 및 이와 관련된 고고학 자료를 비판적으 로 검토한다. 한국 구석기고고학은 한반도 고인류점거사를 서술하는데 있어서 상당히 편향된 정서를 보여주기는 하지만, 고고학 자료 자체는 소위 '홍적세의 모더니티'라 부 를 수 있는 현생 인류의 발생 및 이와 관련된 물질 자료의 획기적인 변화를 전지구적 맥락에서 관찰할 수 있는 잠재적 가능성을 보유하고 있다. 한반도의 고유한 지리적 위 치와 거친 지모를 고려할 때 후기 홍적세 이전에 대규모의 인구 이동이나 높은 인구 밀도 수준이 가능했을 것으로 기대하기는 힘들다. 돌날에 기반하여 제작된 효율적인 후기 구석기 도구 및 이것이 가능하도록 해 주는 정질 석재로의 전이를 통해서 한반도 내에서 홍적세의 모더니티를 관찰할 수 있으며, 이러한 기술적 전이는 현생 인류가 한 반도에 유입되는 시점인 약 4 만년 전부터 진행된다. 그러나 이러한 과정이 진행되는 동안 인구의 분포는 균일하지 않았고, 지역 내 고인류 집단 간의 교류는 상호 간의 접 촉이나 목적 지향적인 작업을 위한 의사소통이 원활하지 않았기 때문에 뚜렷하게 구체 화되지 않았던 것으로 보인다. 그런 의미에서 볼 때 물질 문화에 반영되는 고유한 지 역적 전통은 적어도 구석기 시대가 끝나는 홍적세 이후에야 비로소 구체화된 것으로 볼 수 있을 것이다.

주제어: 홍적세의 모더니티, 구석기, 현생 인류, 고환경, 지역적 전통 